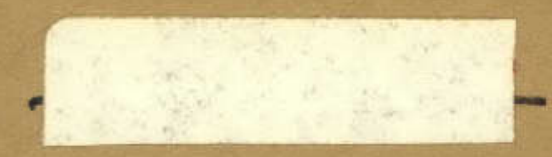

M. F. C. 5967
Copy No. $\$ 2$

I N T E E R I M R R E P O R T T O N

THE B E A V E R MESA A R A, MESA C O U N T Y,

C OLORA D O, A N D G R A D COU N T Y, U T A H

By L. J. Eicher and N. W. Bivens

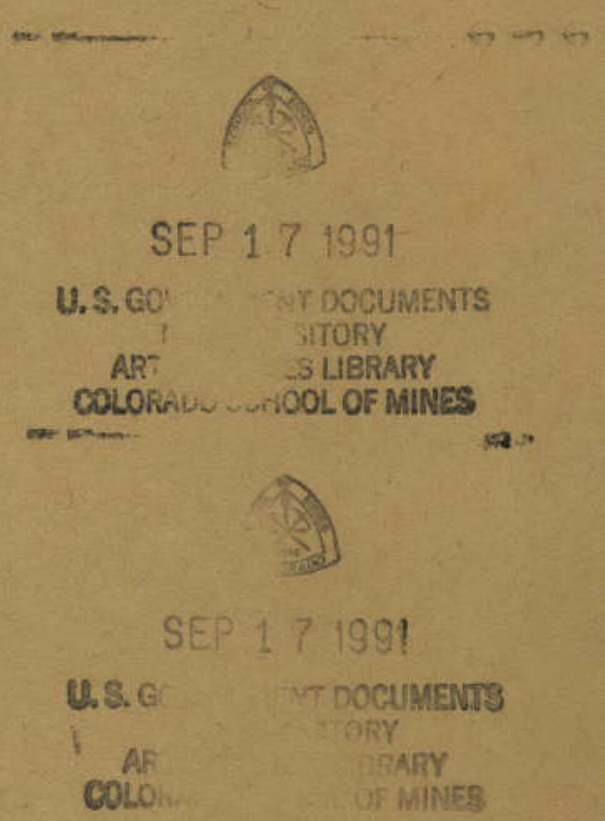

Trace Elements Memorandum Report 711

UNITED STATES DEPARTMENT OF THE INTERIOR

GEOLOGICAL SURVEY 
This document consists of 8 pages, plus 1 figure.

Series A

UNITED STATES DEPARTNENT OF THE INTERIOR

GEOLOGICAL SURVEY

INTERIM REPORT ON EXPLORATTON OF THE BEAVER MESA AREA. MESA COUNTY, COLORADO, AND GRAND COUNTY, UTAH*

L. J. Eicher and N,W. Bivens

January 1955

Trace Elements Memorandum Report 711

This pre_ininary report is distributed without editbrial and chnical review for conformity wa official standards and nomencyare. $\mathrm{Yt}$ is not for public inspection or quotation.

-This report concerns work done on behalf of the Division of Raw Materials of the U. S. Atomic Energy Commission. 
USGS-TEM- 711

GEOLOGY AND MINERALOGY

Distribution (Series A)

No, of copies

Division of Raw Materials, Denver . . . . . . . . . . . . . . . . 01

Division of Raw Materials, Salt Lake City . . . . . . . . . . . . . . . 1

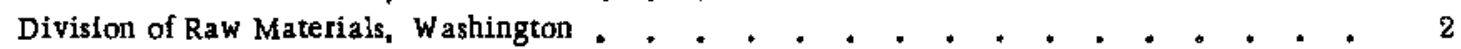

Exploration Division, Grand Junction Operations Office . . . . . . . . . . $\quad 2$

Grand Junction Operation Office . . . . . . . . . . . . . . . . . . . 2

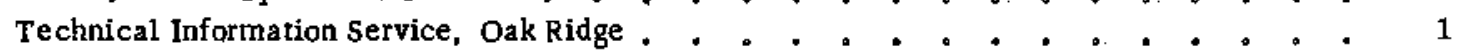

U. S. Geological Survey:

Geochemistry and Petrology Branch, Washington '. . . . . . . . . . . . .1

Geophysics Branch, Washington . . . . . . . . . . . . . . . . . 1

Mineral Deposits Branch, Washington . . . . . . . . . . . . . . . . 1

A. L. Brokaw, Grand Junction . . . . . . . . . . . . . . . . . . 2

P. C. Patton, Denver . . .. . . . . . . . . . . . . . . . . . . . 1

TEPCO, Denver . . . . . . . . . . . . . . .. . . . . . . 1

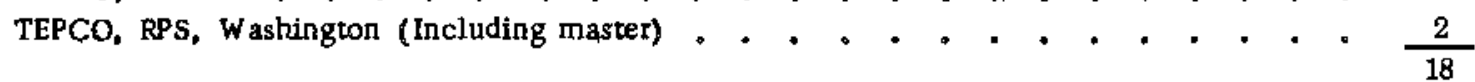


CONTENTS

Page

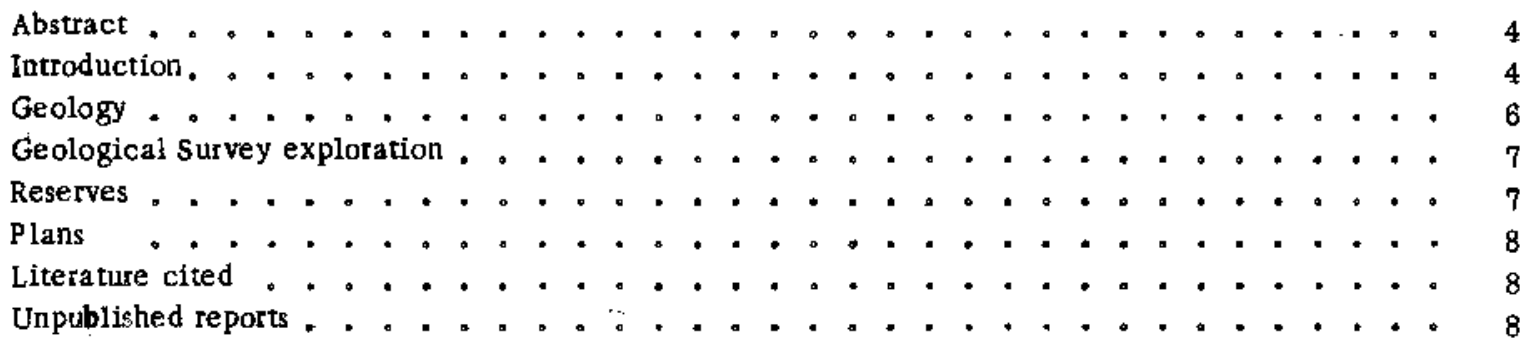

ILLUSTRATION

Figure 1. Geologic map of the Beaver Mesa area, Mesa County, Colorado, and Grand County, Utah ................................ In envelope 


\section{INTERIM REPORT ON EXPLORATION OF THE BEAVER MESA AREA. MESA COUNTY, COLORADO, AND GRAND COUNTY, UTAH}

By $L_{0}, J$ Eicher and $N, W$. Bivens

\section{ABSTRACT}

Beaver Mesa, Mesa County, Colo., and Grand County, Utah, is approximately 12 miles west of Gateway, Colo In 1954 the U. S, Geological Survey diamond-drilied 108 holes totaling 56, 078 feet in the Beaver Mesa area to search for minable uranium-bearing deposits and to appraise the uranium reserves of the area.

Reserves found by the Geological Survey drilling total about 18,000 short tons of indicated and inferred Inaterial. averaging about $0_{0} 4$ percent $\mathrm{U}_{3} \mathrm{O}_{8}$ and $1_{6} 5$ percent $\mathrm{V}_{2} \mathrm{O}_{5}$. The reserves are in masses that average 1, 000 short tons each and are on claimed land。

The Geological Survey has no plans for further exploration drilling in the Beaver Mesa area, The favorable ground outlined by Survey drilling is now being tested by private industry, Surface and sub-surface geologic mapping started in 1954 will continue in the area in order to complete the evaluation of the uranium . potentiai Geologic data from private exploration will be compiled and included in the final report on the are $\mathbf{a}_{a}$

\section{INTRODUCTION}

The Beaver Mesa area is in the western part of the Gateway mining district. The area is bounded by the Dolores River on the eastern and northern sides, Beaver Creek on the western side, and John Brown Creek on the southem side. The area ranges in altitudie from 6,800 to 7,900 feet and is accessible by about 12 miles of improved road which connects with Colorado Highway 141 half a mile south of Gateway, Colo. The explored part of the area includes parts of $\operatorname{secs}_{0} 13,14,23,24,25,26,35$, and $36, T_{0} 51 \mathrm{~N}, \mathrm{R}_{0} 20 \mathrm{~W}$, ; secs, 31 and $32, T, 51 \mathrm{~N}_{0}, \mathrm{R}_{0} 19 \mathrm{~W}_{\mathrm{b}}$ i secs, 1,2, and $11, \mathrm{~T}_{\mathrm{a}} 50 \mathrm{~N}, \mathrm{R}_{\mathrm{o}} 20 \mathrm{~W}_{\mathrm{a}}$. New Mexico principal meridian, Mesa County, Colo, ; and secs, 4, 5, 8, 9, 16, 17, 19 and 20, T. $25 \mathrm{~S}$, R, $26 \mathrm{E}_{a}$, ; sec 33 , T. $24 \mathrm{~S}_{\circ}, \mathrm{R}_{\mathrm{o}} 26 \mathrm{E}_{*}$, Salt Lake meridian, Grand County, Utah (fig. 1), The explored ground is almost 
completely covered by privately owned claims. This area lies within the projected trend of the Uravan mineral belt (Fischer and Hilpert, 1952) and was selected for exploration because geologic reconnaissance indicated the presence of ground favorable for the occurence of uranium-bearing deposits,

Production of the mines in this area, through september 1954, totals about 35,000 short tons of ore a veraging 0,38 percent $\mathrm{U}_{3} \mathrm{O}_{8}$ and $1_{0} 50$ percent $\mathrm{V}_{2} \mathrm{O}_{5}$

Drilling by private companies on Beaver Mesa through October 1954, totals about 100,000 feet。 In the Lumiden Canyon area (fig。 1), the U. S, Vanadium Co, has completed approximately 20, 000 feet of drilligg south of the Lumsden No, 1 and Lumsden No, 2 mines. The Gateway Mining and Development Co, has drilled approximately 17,000 feet in the area south of the La Sal group of mines. The Climax Uranium Co, has drilled approximately 2,000 feet in the Kaywood Point area, and 10, 000 feet in the central and western part of Beaver Mesa. The Lost Dutchman $\mathrm{Co}_{0}$ has drilled approximately 10,000 feet in the area wert and north of Lumsden Canyon. The Ute Uranium $\mathrm{Co}_{0}$ has drilled approximately 5,000 feet in the south-central part of Beaver Mesa, The Cherrokee-Rajah $\mathrm{Co}_{\mathrm{v}}$ has completed approximately $5_{0}, 000$ feet of drilling in several uranium-bearing deposits found by $U_{b} S_{o}$ Geological Survey drilling south of Lumbden Canyon. This company is now sinking a 450-foot shaft to develop one of these deposits. The Simpsom. Mining $\mathrm{Co}_{0}$ has drilled one hole in the south-central part of the are $\mathrm{a}_{0}$

Pick Mining $\mathrm{CO}_{0}$ and Frontier Mining $\mathrm{Co}_{0}$ have done approximately 10,000 feet of drifling east of the Rae Marie and Cedar Point mines, The Boomerang Mining $\mathrm{Co}$, has drilled approximately 9,300 feet in the vicinity of the Corvusite mine. South of the Corvusite mine the Climax Uranium Co, has drilled approximately 3,400 feet An estimated 5,000 feet of drilling has been done by small companies throughout Beaver Mesa. In addition the $U_{0}, S_{0}$ Bureau of Mines drilled 1,876 feet in 21 holes in the vicinity of the Corvusite mine in November 1943 . 
The first diamond-drill exploration project by the Geological Survey in the Beaver Mesa area extended from May 4, 1953, to December 17, 1953, (Eicher and Myers, 1954). The drilling was recessed for winter, was resumed April 13, 1954, and was completed October 30; 1954:- The purpose of this deitling was to search for minable uranium-bearing deposits and to appraise the uranium reserves of the area. The results of the second period of exploration are summarized in this report.

\section{GEOLOGY}

The rocks exposed in the Beaver Mesa area, from oldest to youngest, consist of the Upper Jurassic Morrison formation ( 600 to 690 feet thick), the Lower Cretaceous Burro Canyon formation (210 feet thick), and the Lower and Upper Cretaceous Dakota sandstone (absent to 100 feet thick). The Morrison formation is divided into the Salt Wash member (280 to 340 feet thick), composed dominantly of interstratified units of sandstone and mudstone, and the overlying Brushy Basin member ( 320 to 350 feet thick), composed primarily of variegated red and gray shales and clays and occasionai interbedded conglomeratic sandstone lenses, Overlying the Morrison formation is the Burro Canyon formation, predominantly a conglomeratic sandstone containing lenses of green and gray shales. The Dakota sandstone, which overlies the Burro Canyon formation, is predominantly a resistant conglomeratic sandstone containing thin lenses of gray shale. These formations dip at low angles ( $5^{\circ}$ maximum) in a northeasterly direction toward the axes of the $S$ ager's Wash (Dane, 1935) and Dolores (Cater, 1953) synclines.

All of the significant uranium deposits found in this area are in the uppermost sandstone bed of the Salt Wash member of the Morrison formation, This bed, commonly referred to as the "ore-bearing sandstone," ranges. from 15 to 80 feet in thickness. The ore-bearing sandstone is commonly lenticular and irregularly bedded. In the vicinity of uranium-bearing deposits the mudstone in contact with the sandstone is gray-green. The significant uranium-bearing deposits in the Beaver Mesa area are the unoxidized (or only partially oxidized) uranium-vanadium type, commonly called "black ores" (Weeks and Thompson, 1954). The principal ore minerals are the uranium-bearing minerals uraninite and zoffinite"and the vanadium-bearing minerals montroseite, lumsdenite, and doloresite. 


\section{GEOLOGICAL SURVEY EXPLORATION}

Between May 4 and December 17, 1953, the Geological Survey completed 104 diamond-drill holes for a total of 45,124 feet on the first drilling contract in the Beaver Mesa area (Eicher and Myers, 1954). A second drilling contract was started April 13, 1954, and completed October 30, 1954. On the second contract the Geological Survey completed 108 diamond-drill holes for a total of 56,078 feet. All of the holes were drilled on privately owned claims. Approximately 30 perceat of the footage was utilized in widely spaced holes, 1,000 to 3,000 feet apart, to obtain geologic information that would be useful in the search for uranium-bearing deposits. Approximately 60 percent of the footage was utilized in moderately spaced holes, 500 to 1,000 feet apart, to search for deposits in geologically favorable ground. About 10 percent of the footage was drilled on close-spaced centers, less than 200 feet apart, to define better the size and geologic configuration of certain deposits discovered on wider-spaced drilling.

of the 108 holes, 5 are in material 1 foot or more thick containing $0_{0} 10$ percent or more $\mathrm{U}_{3} \mathrm{O}_{8}$

and/or 1.0 percent or more $\mathrm{V}_{2} \mathrm{O}_{5}$, and 40 holes are in mineralized material containing less than $0_{0} 10$ percent $\mathrm{U}_{3} \mathrm{O}_{8}$ and less than 1.0 percent $\mathrm{V}_{2} \mathrm{O}_{5}$, or is less than 1 foot thick regardless of grade.

\section{RESERVES}

On the basis of a preliminary estimate, about 18,000 short tons of indicated and inferred reserves averaging 0.4 percent $\mathrm{U}_{3} \mathrm{O}_{8}$ and 1.5 percent $\mathrm{V}_{2} \mathrm{O}_{5}$ were found as a result of the Geological Survey drilling in the Beaver Mesa area from May 14, 1953, to October 30, 1954. The reserves are calculated at a grade cutoff of 0.10 percent $\mathrm{U}_{3} \mathrm{O}_{8}$ and/or 1,0 percent $\mathrm{V}_{2} \mathrm{O}_{5}$ for material 1 foot or more thick, About 12000 short tons of the total reserves averaging 0.4 percent $U_{3} O_{8}$ and 1.5 percent $V_{2} O_{5}$ were found during the 1953 drilling and were reported previously (Eicher and Myers, 1954). The remaining 6, 000 short tons of reserves were found during the 1954 drilling. Reserve calculations from drill-bole data showed the 6, 000 short tons to have an average grade of $1_{0} 2$ percent $\mathrm{U}_{3} \mathrm{O}_{8}$ and 5.5 percent $\mathrm{V}_{2} \mathrm{O}_{5}$. A more realistic grade average, based on past production, would be 0.4 percent $\mathrm{U}_{3} \mathrm{O}_{8}$ and 1.5 percent $\mathrm{V}_{2} \mathrm{O}_{5}$. The reserves are all in masses that average 1,000 short tons each. The reserves are all on claimed land. 
Private companies are now drilling in these reserve areas. Information from company drilling will be used to reevaluate the reserves, It is expected that the wnnage of reserves will be increased considerably.

\section{PLANS}

The Geological Survey has no plans for further exploration drilling in the Beaver Mesa area. The favorable ground outlined by Survey drilling is now being tested by private industry. Surface and sub-surface geologic mapping started in 1954, will continue in the area in order to complete the evaluation of the uranium potential. Geologic data from private exploration will be compiled and included in the final report on the area.

\section{LITERAT URE CITED}

Dane, C. H., 1935, Geology of the Salt Valley anticline and adjacent areas, Grand County, Utah; U. S. Geol. Survey Bull. 863 .

Fischer, $R_{0} P_{0}$, and Hilpert, L, S, , 1952, Geology of the Uravan mineral belts U. S. Geol, Survey Bull. 988-A.

Weeks, $A_{0}, D_{0}$ and Thompson, M, E., 1954, Identification end occurrence of uranium and vanadium minerals from the Colorado Plateaus: U. S, Geol, Survey Bull, 1009-B.

UNPUBLISHED REPORTS

Cater, F。 W.. 1953, Geology of the Gateway quadrangle: U. S. Geol. Survey Trace Elements Memo. Rept。696.

Eicher, $L_{0} J_{0}$ and Myers $A_{0} R_{0}$. 1954, Interim report on exploration of the Beaver Mesa area, Mesa County, Colo., and Grand County, Utah; $U_{0}$ S, Geol, Survey Trace Elements Memo. Rept 727. 


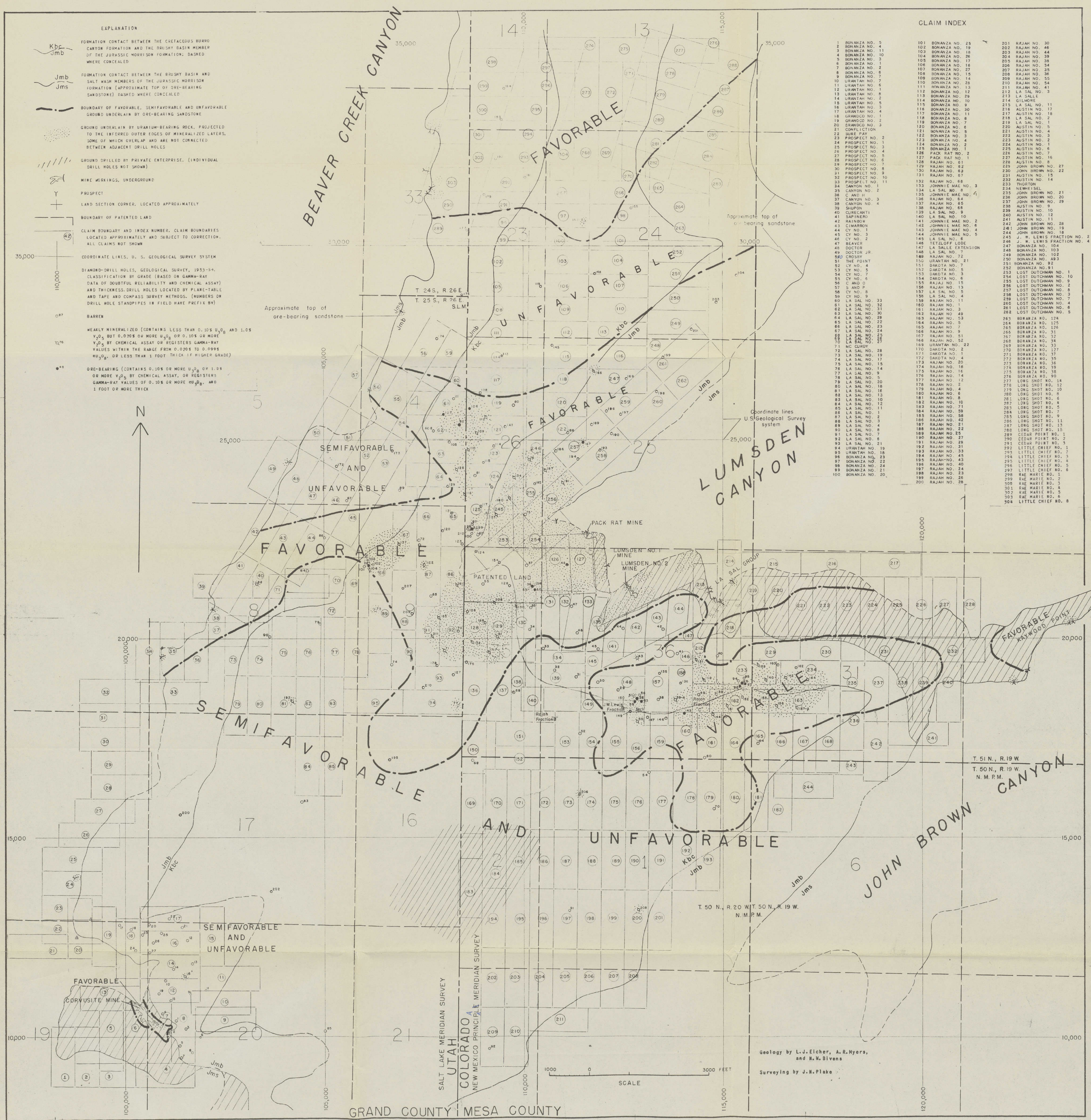

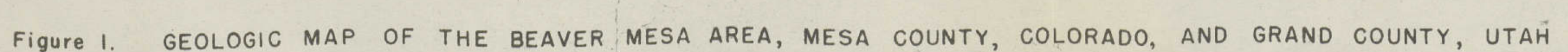




